Article

\title{
Doxorubicin Assisted by Microsecond Electroporation Promotes Irreparable Morphological Alternations in Sensitive and Resistant Human Breast Adenocarcinoma Cells
}

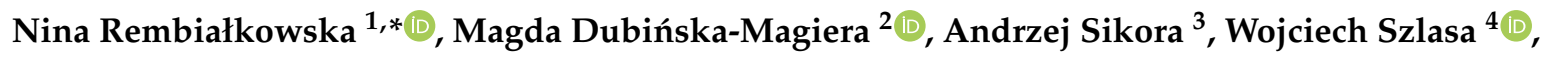 \\ Anna Szewczyk ${ }^{1}$, Hanna Czapor-Irzabek ${ }^{5}$, Małgorzata Daczewska ${ }^{2}$, Jolanta Saczko ${ }^{1}$ and \\ Julita Kulbacka ${ }^{1}$ \\ 1 Department of Molecular and Cellular Biology, Faculty of Pharmacy, Wroclaw Medical University, \\ 50-367 Wroclaw, Poland; a.szewczyk@umed.wroc.pl (A.S.); jolanta.saczko@umed.wroc.pl (J.S.); \\ julita.kulbacka@umed.wroc.pl (J.K.) \\ 2 Department of Animal Developmental Biology, Institute of Experimental Biology, University of Wroclaw, \\ 50-137 Wroclaw, Poland; magda.dubinska-magiera@uwr.edu.pl (M.D.-M.); \\ malgorzata.daczewska@uwr.edu.pl (M.D.) \\ 3 Department of Nanometrology, Faculty of Microsystem Electronics and Photonics, Wroclaw, University of \\ Science and Technology, Janiszewskiego 11/17, 50-372 Wroclaw, Poland; andrzej.sikora@pwr.edu.pl \\ 4 Faculty of Medicine, Wroclaw Medical University, J. Mikulicza-Radeckiego Str., 50-367 Wroclaw, Poland; \\ Wojtek.Szlasa@outlook.com \\ 5 Laboratory of Elemental Analysis and Structural Research, Wroclaw Medical University, 50-367 Wroclaw, \\ Poland; hanna.czapor-irzabek@umed.wroc.pl \\ * Correspondence: nina.rembialkowska@umed.wroc.pl
}

Received: 11 March 2020; Accepted: 13 April 2020; Published: 16 April 2020

check for updates

\begin{abstract}
Electroporation increases the transmembrane transport of molecules. The combination of electric pulses with cytostatic compounds is beneficial for cancer treatment. Doxorubicin (DOX) is a commonly used chemotherapeutic anticancer drug. Its fluorescence properties enable the investigation of drug distribution and metabolism. In this study, doxorubicin was enhanced by electroporation to eliminate cancer cells more effectively. The influence of electroporation on the drug uptake was evaluated in two cell lines: MCF-7/WT and MCF-7/DOX. The intracellular localization of doxorubicin and its impact on the intracellular structure organization were examined under a confocal microscope. Cellular effects were examined with the 3(4,5-dimethylthiazol-2-yl)-2,5-diphenyltetrazolium bromide (MTT) test that estimates the rate of metabolism in viable cells. The ultrastructure (TEM) of tumor cells subjected to the electric field was analyzed. An enhanced doxorubicin efficacy was observed in MCF-7/DOX cells after combination with electroporation. The response of the resistant cell line was revealed to be more sensitive to electric pulses. Electroporation-based methods may be attractive for cancer treatment in human breast adenocarcinoma, especially with acquired resistance. Electroporation enables a reduction of the effective dose of the drugs and the exposure time in this type of cancer, diminishing side effects of the systemic therapy.
\end{abstract}

Keywords: electroporation; electrochemotherapy; breast cancer; electropermeabilization; doxorubicin; MCF-7/WT; MCF-7/DOX

\section{Introduction}

Chemotherapy is frequently the only method that can be offered to cancer patients as a primary, adjuvant or neoadjuvant treatment. However, due to low selectivity of cytotoxic agents and drug 
resistance presented in cancer cells its efficacy is often limited [1-3]. Another obstacle is the cellular membrane hindering the penetration of cytostatic agents into tumor cells [1]. Electropermeabilization $(\mathrm{EP})$ is a biophysical method, based on the application of intense electrical pulses to cells in vitro or tissues in vivo, used to increase the uptake of various micro- and macro-molecules [4-6]. This method can be applied to a variety of cell types, including human cells, animal and plant cells $[7,8]$. Electric field intensity, pulse duration and number of pulses are key parameters for optimal transfection efficiency $[9,10]$. Depending on applied pulse modalities, electroporation can be reversible or irreversible. In the first case, nanoscale pores are formed on the cell membrane which is further resealed without affecting cell viability. Irreversible EP (IRE) happens when applied voltage is high enough to damage the cell membrane and as a consequence, lead to cell lysis. IRE has been proposed as a method of nonthermal, minimally invasive ablation [11,12]. On the other hand, Reversible EP has been used for the enhancement of intracellular drug transport $[13,14]$. This process in which cells are subjected to the action of pulsed electric fields in the presence of cytotoxic agents is called electrochemotherapy (ECT). The most popular cytotoxic drugs used clinically is bleomycin, which is hydrophilic and impermeant to cancer cells under normal circumstances [15]. After ECT in the site of application of electric pulses, bleomycin readily enters into the cells [16].

Breast cancer is the most common malignancy in women worldwide [17]. Cancer of the mammary gland grows slowly and symptoms appear relatively late. Good prognosis depends mainly on its stage, and late detection of the tumor increases the likelihood of metastases. The group of anti-cancer antibiotics used to treat breast cancer are anthracyclines (e.g., doxorubicin, daunorubicin) [18,19]. Anthracyclines are produced by soil fungus strains, Streptomyces. Anthracyclines work by reducing topoisomerase II activity and intercalation, i.e., building up between DNA strands [20-22]. These drugs are cell cycle-specific. Cancerous tumors are characterized by cell division, which is no longer controlled and not limited by cell division. The ability of chemotherapy to kill cancer cells depends on its ability to weaken cell proliferation and finally tumor progression [23]. Doxorubicin is a widely used chemotherapeutic agent. Despite its utility, its use causes several adverse side effects, common among which are nausea, vomiting, diarrhea, mouth sores, and hair loss. The most severe are its reversible nephrotoxicity and irreversible dilated cardiomyopathy, leading to congestive heart failure [24]. The irreversible effects of taking doxorubicin cause a limit to the amount of doxorubicin you can receive in your lifetime [25]. The concentrations of drugs used in combination with electroporation are lower, hence, doxorubicin is an ideal chemotherapeutic for exploration.

Electroporation of cell membranes with the simultaneous use of chemotherapeutics allows for the reduction of the drug dose. There is a need to introduce alternative protocols for cases which are insensitive to chemotherapy and to introduce neoadjuvant therapies. Electrochemotherapy is becoming more available and popular with bleomycin or cisplatin as approved for this method. However, other standard cytostatics also need to be validated for potential application in ECT. Cancer cell death induced by standard chemotherapy occurs by apoptosis or necrosis. The implementation of pulsed electric fields would trigger this process more efficiently, affecting more designedly nucleus, mitochondria, endoplasmic reticulum and lysosomes [24-28]. The aim of the present study was to assess the anticancer potential of electrochemotherapy with doxorubicin in drug-sensitive and drug-resistant breast cancer in vitro. Our previous studies have demonstrated that electroporation is a highly effective method for increased intracellular transport of poorly permeable agents [14,29-31]. Here, we hypothesized that EP can be used equally as effectively to increase the therapeutic efficacy of drug, easily penetrating through the cell membrane.

\section{Materials and Methods}

\subsection{Cell Culture}

The study was performed on two human breast adenocarcinoma cell lines: doxorubicin-sensitive (MCF-7/WT) and doxorubicin-resistant (MCF-7/DOX). Cells were grown in Dulbecco's Modified 
Eagle's Medium (DMEM) supplemented with $100 \mathrm{IU} / \mathrm{mL}$ Penicillin, and $0.1 \mathrm{mg} / \mathrm{mL}$ Streptomycin and $10 \%$ Fetal Bovine Serum. All drugs and chemicals were purchased from Sigma-Aldrich (Taufkirchen, Germany), unless noted otherwise. The cell lines were cultured in the polystyrene flasks 25 or $75 \mathrm{~cm}^{2}$ (Thermo Fisher Scientific, Waltham, MA, USA), which were stored in $37^{\circ} \mathrm{C}$ and $5 \% \mathrm{CO}_{2}$ in the incubator (SteriCult, Thermo Scientific, Alab). Both cell lines were grown in monolayers and harvested during the phase of exponential growth using the Trypsin solution (Trypsin $0.25 \%$ trypsin-EDTA).

\subsection{Chemosensitivity Tests}

In the first stage of the study, we assessed the toxicity of doxorubicin (DOX) towards two cell lines: sensitive (MCF-7/WT) and resistant to doxorubicin (MCF-7/DOX). The cells were seeded in 96-well plates, allowed to attach for $24 \mathrm{~h}$ and subsequently exposed to drugs for $10 \mathrm{~min}$, then cells were incubated with DMEM to assess the long-term influence of different concentrations on cell viability. The 3(4,5-dimethylthiazol-2-yl)-2,5-diphenyltetrazolium bromide (MTT assay) test was used for the assessment of cell viability. MTT assay was performed at 24,72 and $120 \mathrm{~h}$. Then the medium of each well was replaced with $10 \mu \mathrm{L}$ of $0.5 \mathrm{mg} / \mathrm{mL}$ MTT stock solution diluted in $90 \mu \mathrm{L}$ phosphate-buffered saline (PBS). MTT assay is a colorimetric method that estimates the rate of metabolism in viable cells. After $2 \mathrm{~h}$ of incubation, isopropanol with $0.04 \mathrm{M} \mathrm{HCl}$ was added $(100 \mu \mathrm{L} /$ well). The absorbance was determined using a multiwell scanning spectrophotometer at $570 \mathrm{~nm}$ (EnSpire ${ }^{\circledR}$ Multimode Plate Reader, Perkin Elmer, Waltham, MA, USA). Mitochondrial function was expressed as a percentage of viable cells under treatment relative to vehicle control.

Cells were treated with aqueous DOX solution in a concentration range of $0.017 \mu \mathrm{M}-170 \mu \mathrm{M}$. For further study with EP 1.7 $\mu \mathrm{M}$, DOX concentration was selected. The cells were seeded into 96-well microculture plates (Nunc, Biokom, Warsaw) at a concentration of $150 \times 10^{3}$ cells/well incubated for $24 \mathrm{~h}, 100 \times 10^{3}$ cells/well incubated for $72 \mathrm{~h}$ and $50 \times 10^{3}$ cells/well incubated for $120 \mathrm{~h}$ at $37^{\circ} \mathrm{C} 5 \% \mathrm{CO}_{2}$.

\subsection{Electropermeabilization Protocol}

Electropermeabilization alone and in the presence of doxorubicin was performed using ECM830 Square Wave Electroporation System (BTX Harvard Apparatus, Syngen Biotech, Poland). For the experiments, cells were detached by trypsinization and neutralized by cell culture medium. Cell cultures were washed in electroporation buffer with low electrical conductivity $0.12 \mathrm{~S} / \mathrm{m}(10 \mathrm{mM}$ $\mathrm{KH}_{2} \mathrm{PO}_{4} / \mathrm{K}_{2} \mathrm{HPO}_{4}, 1 \mathrm{mM} \mathrm{MgCl} 2,250 \mathrm{mM}$ sucrose, $\mathrm{pH}$ 7.4) [32,33]. Aliquots of the final cell suspension in electroporation buffer $\left(1 \times 10^{6}\right.$ cells in $\left.400 \mu \mathrm{L}\right)$ were placed in aluminum cuvettes $(4 \mathrm{~mm}$ gap cuvette, Electroporation Cuvettes Plus 640, BTX). We used Petri Pulser applicator (BTX Harvard Apparatus) for samples intended for confocal and metallurgical microscope analysis. Cells were subjected to ESOPE standard parameters: 8 electric pulses, duration of $100 \mu \mathrm{s}$, electric field intensity $1000 \mathrm{~V} / \mathrm{cm}$ at frequency of $1 \mathrm{~Hz}$ with or without $1.7 \mu \mathrm{M}$ DOX [34]. Two aliquots of cell suspension (with DOX and drug-free) were not subjected to electric shocks and served as the control. After pulsation, cells were left for $10 \mathrm{~min}$ at $37^{\circ} \mathrm{C}$ in a humidified atmosphere containing $5 \%$ of $\mathrm{CO}_{2}$, then cells were centrifuged, resuspended in complete cell culture medium and prepared for further analysis.

\subsection{Doxorubicin Fluorescence Spectra}

Both cell lines were seeded on the culture plates and after $24 \mathrm{~h} 1.7 \mu \mathrm{M}$ DOX was applied. The whole system was incubated for $10 \mathrm{~min}$. Afterwards, the medium was replaced with PBS. The samples of the solution were collected after 2, 3, 6 and $24 \mathrm{~h}$. Cells were left at $37^{\circ} \mathrm{C}, 5 \%$ of $\mathrm{CO}_{2}$. The absorption spectra of solutions without and after the application of electrical pulses were recorded with the SPARK reader. Doxorubicin was excited using $\lambda_{\mathrm{exc}}=470 \mathrm{~nm}$ (30 pulses) and the emission was recorded at $595 \mathrm{~nm}$. Each sample was repeated 3 times. 


\subsection{Doxorubicin Mass Spectroscopy Analysis}

The mass spectrometry analysis of DOX solutions with and without the application of electrical pulses were recorded with Bruker Daltonik apparatus. Solution's components were chromatographically separated by the use of HPLC—Thermo Scientific Ultimate 3000 with pump model: LPG-3400SD, autosampler WPS-3000TSL, thermostat column TCC-3000SD, UV diode detector DAD-3000, refractometry detector RI, RefractoMax 521 and fluorescence detector FLD-3400RS. Chromatographic separations were achieved on the column by gradient elution using mobile phases of (A) $0.1 \%$ formic acid-water and (B) acetonitrile. In general, the chromatographic conditions were used from Wenzhuan Ma et al. [35]. The mass spectrometer was operated in the positive ionization mode after confirmation of poor resolution in the negative mode. Collision energy was set at $15 \mathrm{eV}$ for doxorubicin. The mass scan range was set at 50-1500 m/z. Obtained spectra were analyzed with Burker Compass DataAnalysis 4.2 software.

\subsection{Intracellular Localization of Doxorubicin}

Cells were harvested from the culture flasks and seeded on cover glasses $(24 \times 24 \mathrm{~mm}$, Thermo Fisher Scientific) in $35 \mathrm{~mm}$ Petri dishes (Nunc). The cells not subjected to electropermeabilization were incubated with DOX $\left(1.7 \mu \mathrm{M}, \lambda_{\mathrm{Ex}}=473 \mathrm{~nm}, \lambda_{\mathrm{Em}}=590 \mathrm{~nm}\right)$ for $1-18 \mathrm{~h}$ in complete culture medium. In case of EP-treated cells, the medium was removed and $1 \mathrm{~mL}$ of EP buffer with compounds was added; adherent cells were pulsed on the cover glasses, using Petri Pulser applicator (BTX Harvard Apparatus) with ECM 830 generator. After 10 min of incubation in $37^{\circ} \mathrm{C}$, the buffer with DOX was removed. Then, cells were incubated in complete culture medium for 1-18 h. After that time, cells were stained with the CellMask ${ }^{\mathrm{TM}}$ Deep Red plasma membrane stain $\left(2.5 \mu \mathrm{g} / \mathrm{mL}\right.$, Life Technologies, $\lambda_{\mathrm{Ex}}=635 \mathrm{~nm}$, $\lambda_{\mathrm{Em}}=666 \mathrm{~nm}$ ) for $30 \mathrm{~min}$. After plasma membrane staining the cells were washed in PBS, fixed in $4 \%$ paraformaldehyde (Polysciences, Inc., Warrington, PA, USA) and washed in PBS. To stain cell nuclei, samples were fixed with the DAPI solution (Roti ${ }^{\circledR}-$ Mount FluorCare DAPI Roth). The cells were examined using a Laser Scanning Confocal Microscope Olympus FV1000 (LSCM, Olympus, Poland).

\subsection{Metallurgical Microscope}

For the measurements the inverted optical microscope MA200 from Nikon was used. The device provides variable set of magnifications in A range from 10 to 2000. The most important features used in the research were the Nomarski contrast, providing the incident light phase detection based on the interference phenomena and the dark field observation, enabling the acquisition of the light dispersion on the objects. In addition, advanced software allows the processing of data according to the needs of user. Cells were trypsinized and seeded on cover glasses $(24 \times 24 \mathrm{~mm}$, Thermo Fisher Scientific) in $35 \mathrm{~mm}$ Petri dishes (Nunc). After electropermeabilization the cells were fixed $10 \mathrm{~min}$ in $4 \%$ paraformaldehyde (Polysciences, Inc.) and washed in PBS.

\subsection{Transmission Electron Microscope (TEM)}

The ultrastructural analysis after electropermeabilization alone and with DOX, was carried out by transmission electron microscope Zeiss EM 900. Final DOX concentration in a cell culture was $1.7 \mu \mathrm{M}$. Immediately after pulsation the cells were fixed for $30 \mathrm{~min}$ in $2.5 \%$ (vol/vol) glutaraldehyde and $0.1 \mathrm{M}$ phosphate buffer ( $\mathrm{pH} 7.4$ ). After post-fixation in $1 \%$ (wt/vol) osmium tetroxide, cells were dehydrated through a graded series of alcohol and propylene oxide, and embedded in Epon. The Epon blocks were cut on a Reihert Ultracut E ultramicrotome. Ultrathin sections were contrasted with uranyl acetate and lead citrate according to the standard method [36] and examined with a TEM Zeiss EM 900 (Carl Zeiss, Oberkochen, Germany). 


\subsection{Statistical Analysis}

The results were reported as mean \pm standard deviation. The significance of the difference between the mean values of different groups of cells was assessed by Student's $t$-test with $p$-value of ${ }^{*} p \leq 0.05$; to show the statistical significance. Results were analyzed by commercial software Statistica 10.0 (Statsoft, Kraków, Poland).

\section{Results}

The obtained results indicated that both cell lines, the sensitive one to doxorubicin and the resistant one, showed sensitivity to doxorubicin as the concentration increased (Figure 1). Mitochondrial activity test was used for the assessment of cell viability. The viability of the sensitive cells after 24 and $72 \mathrm{~h}$ of incubation was not strongly affected as the subsequent increase was visible after $120 \mathrm{~h}$ of incubation. No cytotoxic effect for both cell lines was observed using $1.7 \mu \mathrm{M}$ DOX and this concentration was selected for further study.
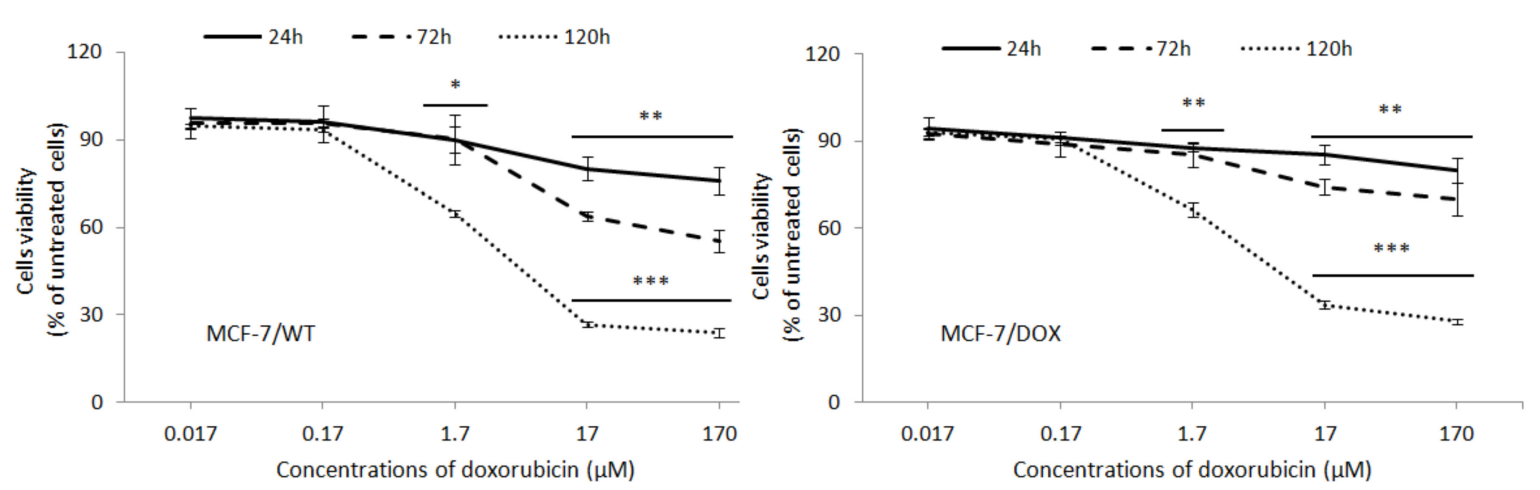

Figure 1. The results of the 3(4,5-dimethylthiazol-2-yl)-2,5-diphenyltetrazolium bromide (MTT) assay following cytotoxicity tests with doxorubicin (DOX) at a range of $0.017-170 \mu \mathrm{M}$ concentration on human breast adenocarcinoma cell lines sensitive (MCF-7/WT) and resistant to doxorubicin (MCF-7/DOX). After being incubated for 10 min with DOX, cells were incubated in complete culture medium 24, 72 and $120 \mathrm{~h}$. Statistically significant differences between DOX-treated cells and nontreated control (* $\left.p \leq 0.05 ;{ }^{* *} p \leq 0.005 ;{ }^{* * *} p \leq 0.001\right)$.

An enhanced doxorubicin efficacy was observed in MCF-7/DOX cells when it was combined with electroporation (Figure 2). The most significant difference in cell viability was observed following $120 \mathrm{~h}$ incubation after ECT with $1.7 \mu \mathrm{M}$ DOX concentration and electric field strength, with respect to the untreated control. The response of the resistant cell line indicates that it can be more sensitive to EP.

The fluorescence intensity of DOX and DOX solutions subjected to electrical pulses is shown Figure 3. The fluorescence intensity of the DOX solution was at the level of $1.3-1.4 \times 10^{6}$, and its max was $1.425 \times 10^{6}$. After the application of electrical pulses, the fluorescence intensity of DOX was about $1.1-1.2 \times 10^{6}$, and its max was $1.254 \times 10^{6}$. The difference in absorption is related to the photosensitive properties of DOX and the application of the electric pulses causing decrease in the fluorescent signal of DOX.. In order to validate if the doxorubicin's structure was affected by the electric field used in the in vitro experiments, mass spectrometry analysis was performed. The spectra of DOX without (Figure 4a) and with the application of the electric pulses (Figure 4b) used in the electroporation protocol do not differ from each other. In both cases, the only present compound in the solution was doxorubicin (100\% precision). 


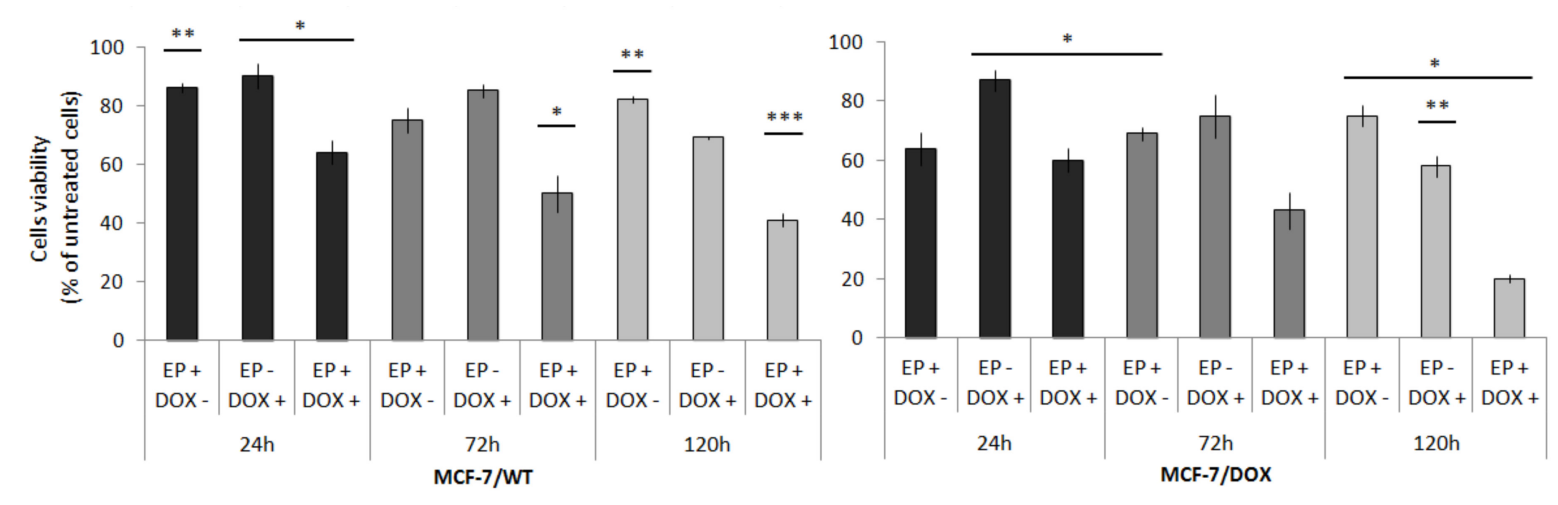

Figure 2. The results of MTT assay following the application of electric pulses ((EP+) 8 pulses, duration of $100 \mu \mathrm{s}$, electric field intensity $1000 \mathrm{~V} / \mathrm{cm}, 1 \mathrm{~Hz}), \mathrm{DOX}$ alone (DOX+) and following electrochemotherapy $(\mathrm{ECT})(\mathrm{EP}+\mathrm{DOX}+)$ on human breast adenocarcinoma cell lines sensitive (MCF-7/WT) and resistant to doxorubicin (MCF-7/DOX) cell lines after 24, 72 and $120 \mathrm{~h}$ of incubation. Statistically significant differences between cells exposed to EP/DOX treated/ECT and nontreated control ( $p \leq 0.05 ;{ }^{* *} p \leq 0.005$; *** $p \leq 0.001)$.

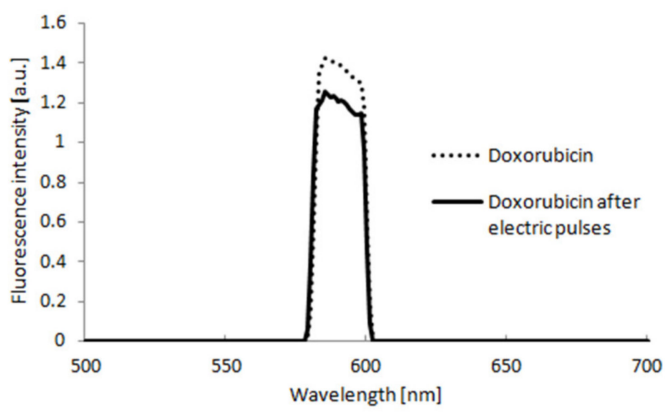

Figure 3. Fluorescence intensity of doxorubicin solutions without and after application of electrical pulses.

The relative fluorescence of the DOX solutions with and without the application of the electric pulse indicate a statistically significant difference between the cell lines (Figure 5). Interestingly, it was observed that MCF-7/WT cells were losing the doxorubicin fluorescent signal after electroporation. The effect of EP was not so apparent for MCF-7/DOX cells. According to Figure 5b, EP had no statistically significant impact on doxorubicin fluorescence in resistant cells. Considering the time-dependence of DOX efflux, it could be observed that the statistical differences occur only in shorter $(2,3,6 \mathrm{~h})$ incubation times and the differences diminish after $24 \mathrm{~h}$ of incubation. Electroporated MCF-7/DOX did not differ statistically from the control cells. However, electroporated MCF-7/WT cells released less DOX to the solution.

Intracellular distribution of DOX is presented in Figure 6 for sensitive cell line (MCF-7/WT) and in Figure 7 for resistant cell line (MCF-7/DOX). In both cell lines, DOX signal was stronger in non-electroporated cells and the drug localized mainly in the cell nucleus. The DOX fluorescence intensity increased proportionally to the time of drug incubation in both cell lines, and MCF-7/WT cells exhibited a stronger signal than MCF-7/DOX. Only individual MCF-7/DOX cells showed a significant DOX signal after $15 \mathrm{~h}$ of incubation. The morphological changes manifested by the irregular shape of the nuclei were observed for MCF-7/WT $18 \mathrm{~h}$ after ECT application. 

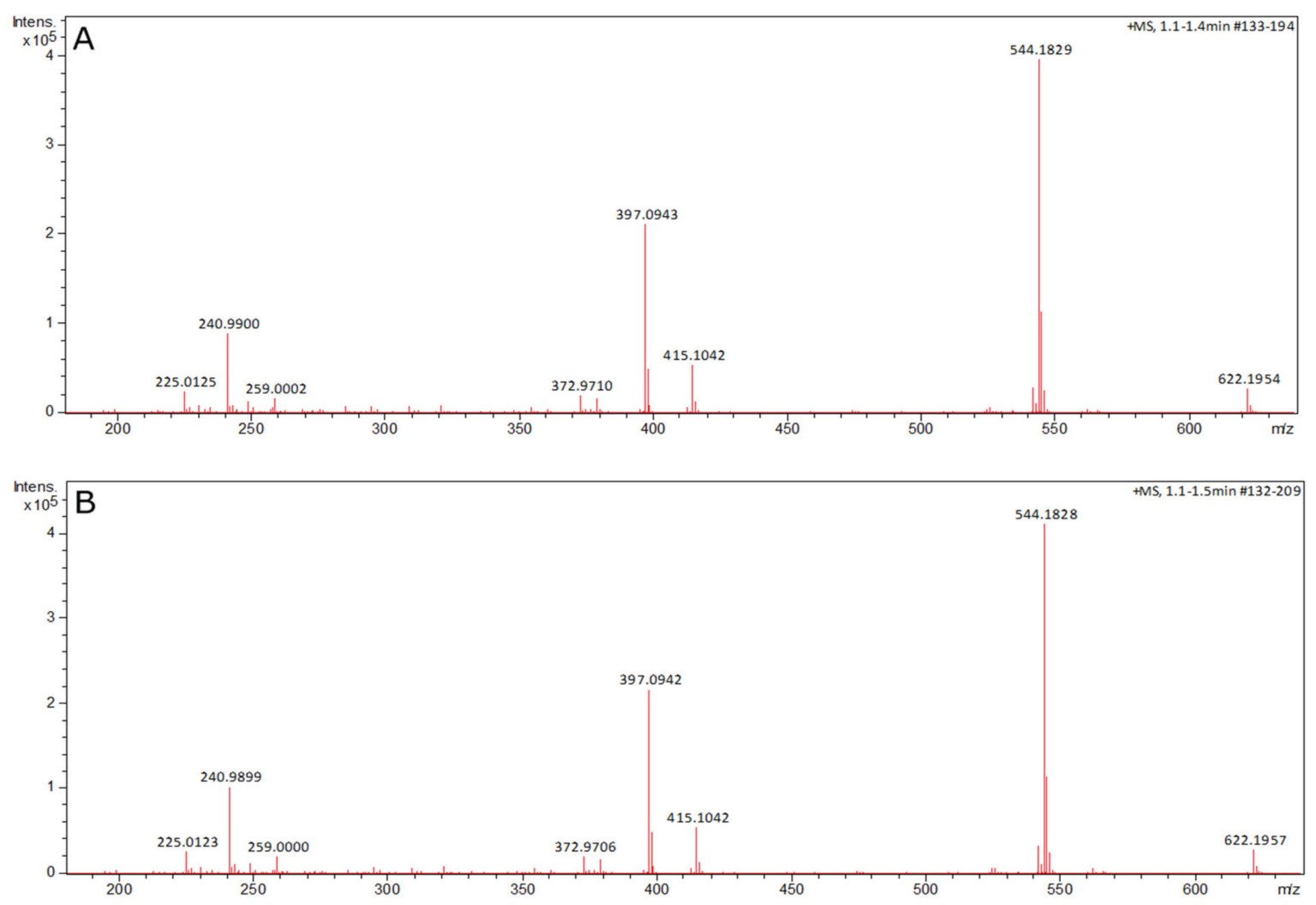

Figure 4. Mass spectrometry spectra of doxorubicin (A) and after application of 8 electric pulses, duration of $100 \mu \mathrm{s}, 1000 \mathrm{~V} / \mathrm{cm}$ each (B).
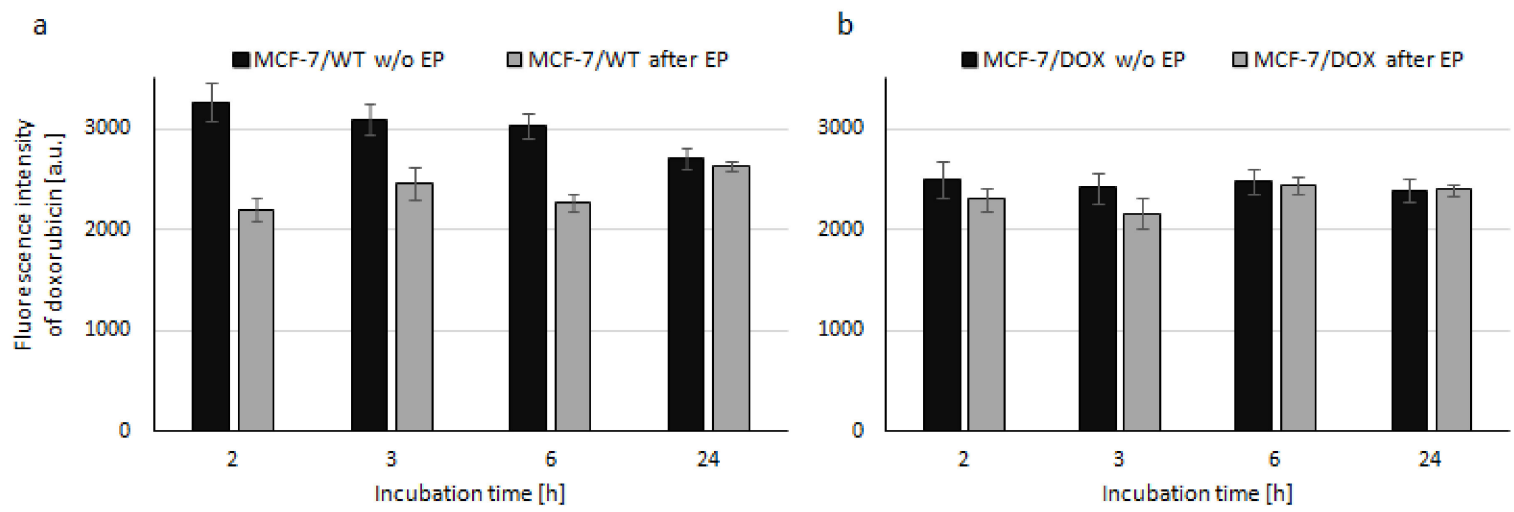

Figure 5. Relative fluorescence of doxorubicin in the supernatant of the (a) MCF-7/WT and (b) MCF-7/ DOX cells without and after the application of electrical impulses.

The combination of DOX with electroporation resulted in a reduction of the DOX fluorescent signal and altered drug distribution. DOX was dispersed throughout the cytoplasm and in cellular compartments in both cell lines. The disintegration of cell structure and cell death was observed after at least $12 \mathrm{~h}$ of ECT, but the toxic effect was stronger in MCF-7/WT than MCF-7/DOX. Additionally, the total nuclei lysis in MCF-7/WT was noted. MCF-7/DOX morphology was changed by ECT i.e., cell membrane was disrupted and nuclei showed irregular shape, but damages were not as significant as for MCF-7/WT. Electroporation is a physical process, which seems not to be dependent on the resistance of the cell line to a certain drug. Therefore, combining these results with the DOX fluorescence studies (Figure 5), there could be stated, that electroporation decreases the concentration of the drug in the cytoplasm of both cell lines. However, the decrease in MCF-7/DOX is simultaneous and the drug 
concentration in the supernatant is not affected by the application of an electric field. One of the reasons for that could be the increased activity of DOX-metabolizing enzymes. Such enzymes could include specific MCF-7/DOX efflux pumps, which could simultaneously release the drug from the cells.

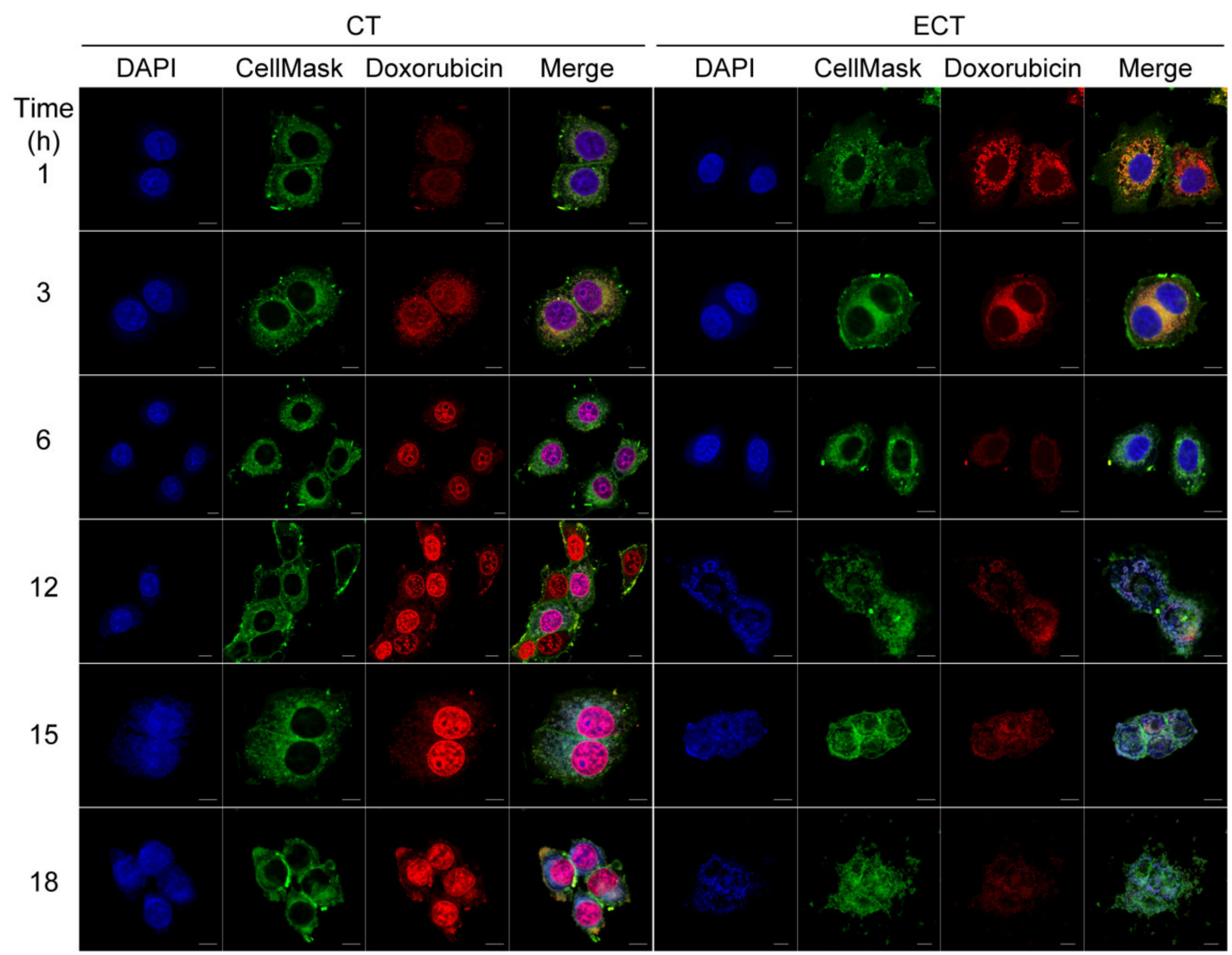

Figure 6. Intracellular distribution of doxorubicin $(\mathrm{DOX}=1.7 \mu \mathrm{M})$ in MCF-7/WT cells treated with chemotherapy only (CT) or electropermeabilized with DOX (ECT, EP-DOX) $(\mathrm{EP}=1000 \mathrm{~V} / \mathrm{cm}, 100 \mu \mathrm{s}$, 8 pulses, $1 \mathrm{~Hz}$ ) after different incubation times. Scale bar $=10 \mu \mathrm{m}$.

In this research features of Nomarski contrast and the dark field observation (Figure $8 \mathrm{MCF}-7 / \mathrm{WT}$, Figure 9 MCF-7/DOX) were used. Nomarski contrast provides the incident light phase detection based on the interference phenomena. The resulting image can reveal the difference between two closely spaced points. The image has the appearance of a three-dimensional object under very oblique illumination, causing strong light and dark shadows. This type of microscopy that can capture images of transparent objects without the need for chemical staining are of a significant importance. A key feature is the use of a long focal length and non-contact metallurgical objectives which avoid the need for coverslips. The morphological changes manifested by the irregular shape of the cells (bulges) were observed for both cell lines within $24 \mathrm{~h}$ after electroporation, consistent with prior research. Cells exposed to electroporation were more flattened than the not treated samples, in particular the nucleus, and this resulted in significant alternations of cell morphology.

The ultrastructural morphology of human breast adenocarcinoma doxorubicin-sensitive MCF-7/WT are presented in Figure 10a-d and doxorubicin-resistant MCF-7/DOX in Figure 11a-d. Untreated MCF-7/WT cells (Figure 10a) presented normal morphological structures. We observed a regularly shaped nucleus with nuclear envelope invaginations, mitochondria, RER and lysosomes. After exposure to DOX (Figure 10b) extended rough endoplasmic reticulum occurred. 


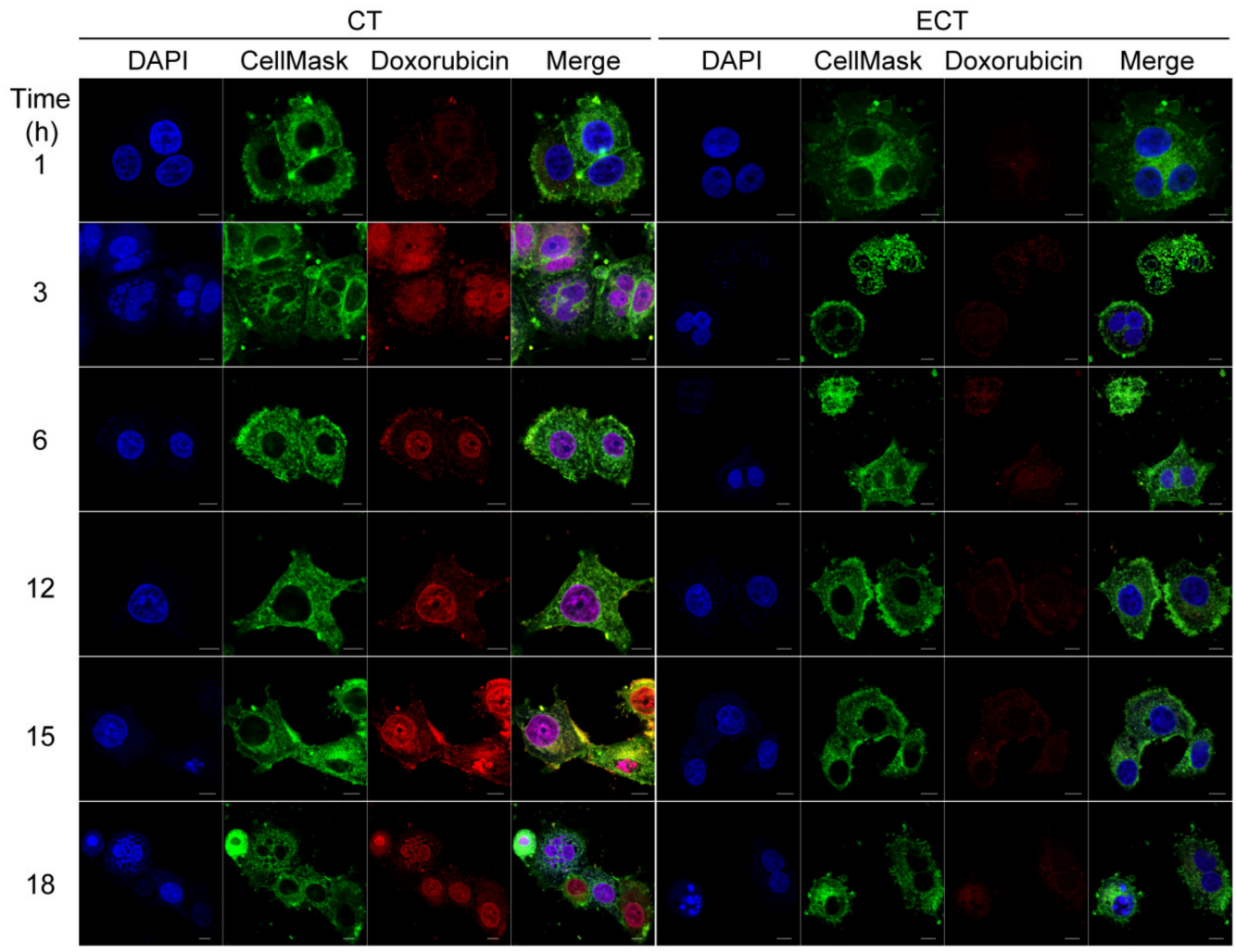

Figure 7. Intracellular distribution of doxorubicin $(\mathrm{DOX}=1.7 \mu \mathrm{M})$ in MCF-7/DOX cells treated with chemotherapy only (CT) or electropermeabilized with DOX (ECT, EP-DOX) $(\mathrm{EP}=1000 \mathrm{~V} / \mathrm{cm}, 100 \mu \mathrm{s}$, 8 pulses, $1 \mathrm{~Hz}$ ) after different incubation times. Scale bar $=10 \mu \mathrm{m}$.

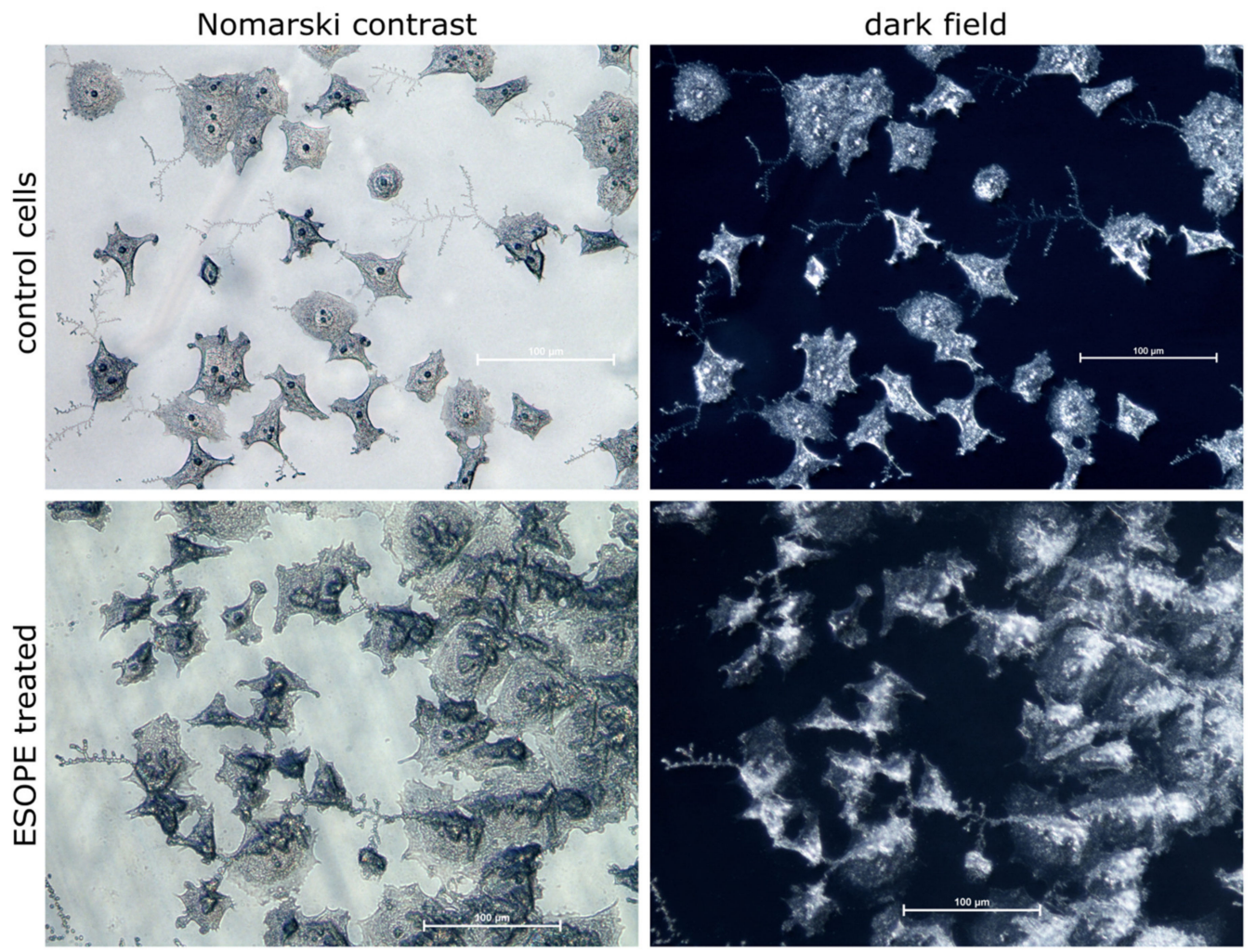

Figure 8. Visualization of morphology by Nomarski interference contrast microscopy of control MCF-7/WT cells and after application of electrical pulses (ESOPE parameters) within $24 \mathrm{~h}$ of incubation. 

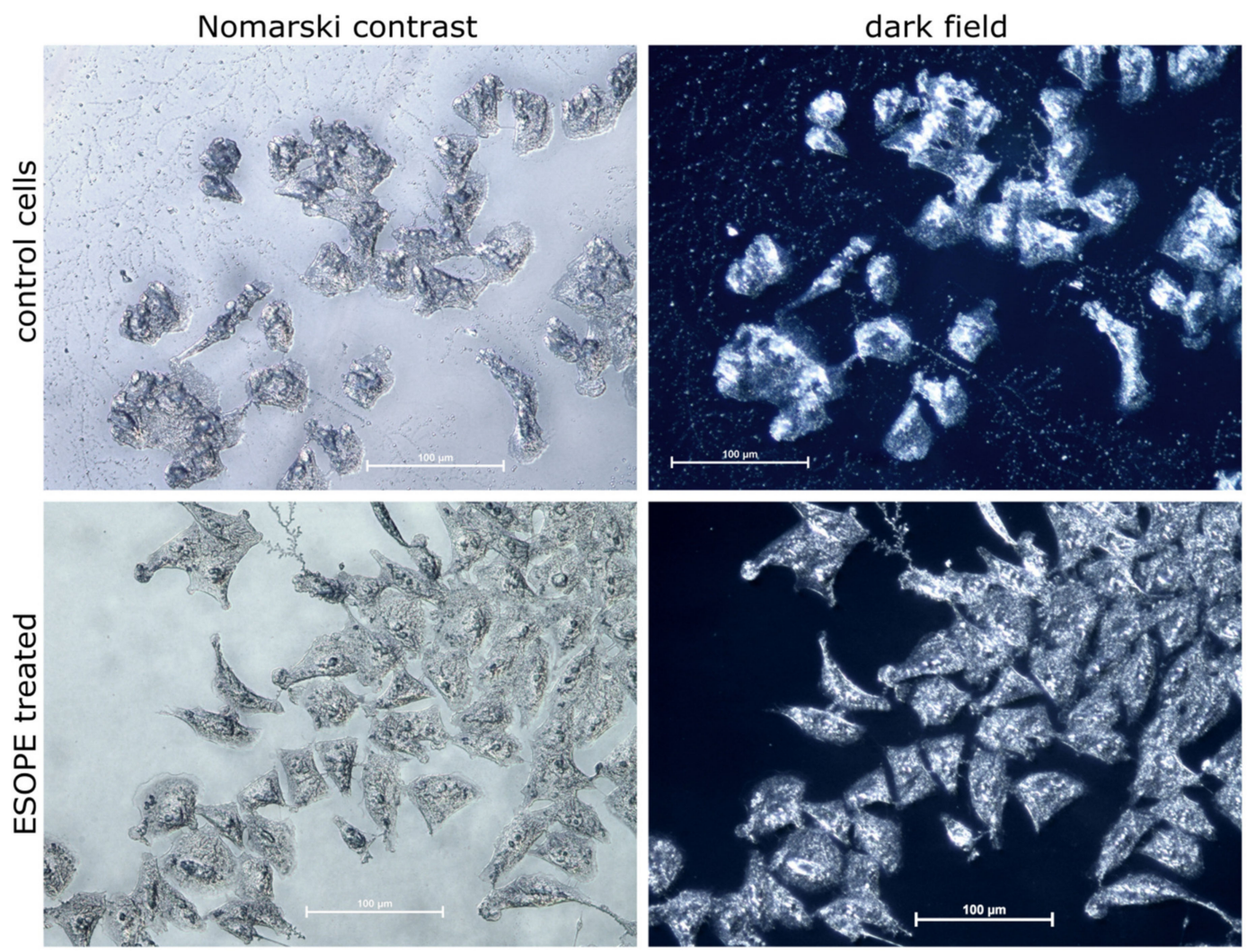

Figure 9. Visualization of morphology by Nomarski interference contrast microscopy of control MCF-7/DOX cells and after application of electrical pulses (ESOPE parameters) within $24 \mathrm{~h}$ of incubation.

The following changes in shape and inner structure of mitochondria were observed: smaller rounded mitochondria with densely packed cristae and bigger mitochondria with marginal cristae with a granular and homogenous inner compartment. After electropermeabilization alone (Figure 10c), an abundance of abnormal vacuoles with fibrous, heterogeneous and flocculent material were detected. Some large vesicles were situated at the periphery of the cells, containing only membranes, which suggests that their digested content had been eliminated during fixation. When an electric field was applied simultaneously with DOX (Figure 10d) the diversification in shape and inner structure of mitochondria was observed: an elongated shape and position closer to the cell membrane. Most cells contained vesicles corresponding to small roughly spherical primary lysosomes with homogenous dark content, and much larger and more irregularly shaped secondary lysosomes with heterogeneous content. Some vesicles of similar diameter contained clusters of numerous small vesicles, often enveloped in a membrane, so forming a multivesicular bodies in addition to heterogeneous material characteristic to secondary lysosomes. These compartments were surrounded by a double membrane suggesting that multivesicular bodies might engulfed in a large vesicle that had already fused with primary lysosomes. 


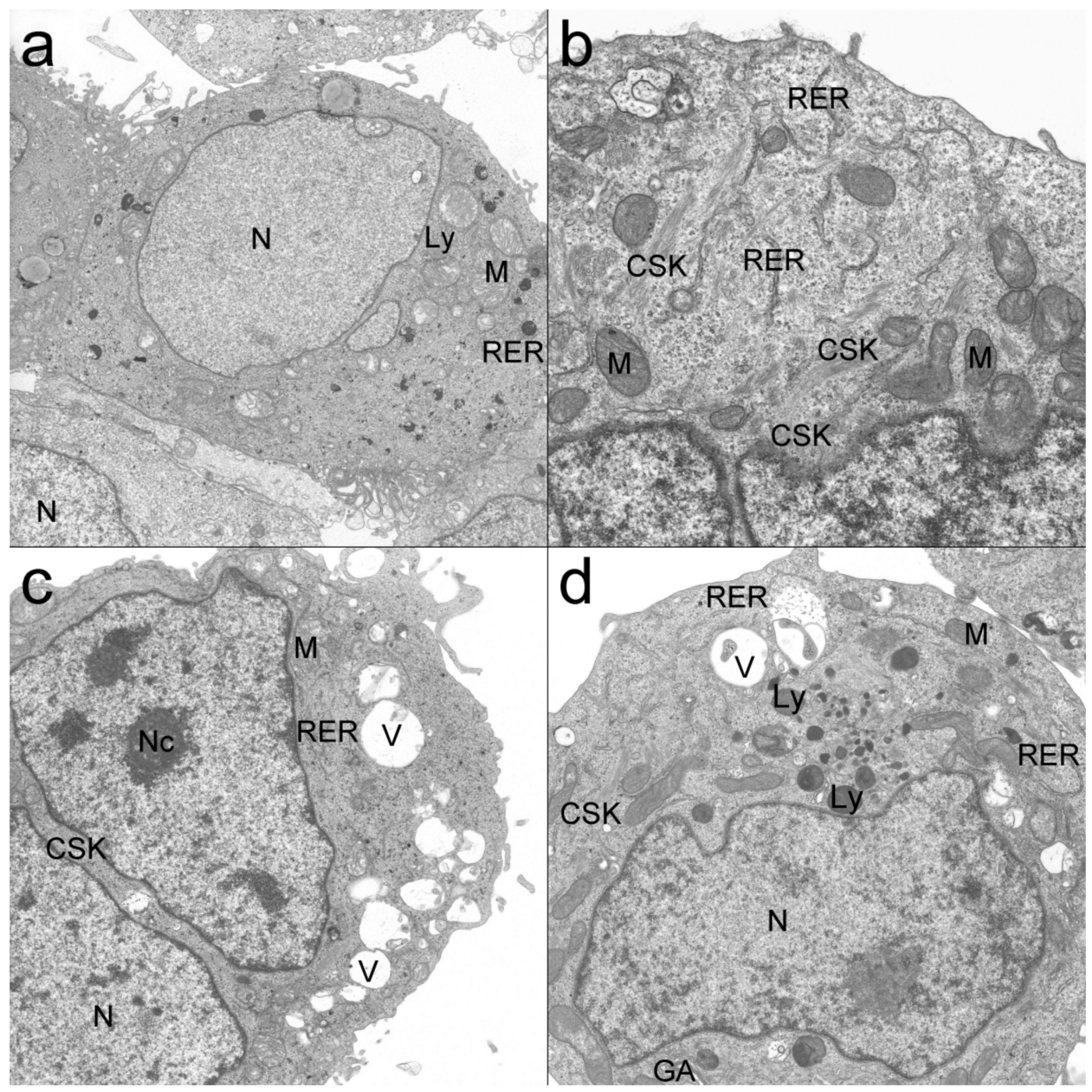

Figure 10. Ultrastructure of breast adenocarcinoma doxorubicin-sensitive cells (MCF-7/WT). (a) —Control, nontreated cells; (b) - Cells after exposure to doxorubicin $(\mathrm{DOX}=1.7 \mu \mathrm{M}) ;(\mathbf{c})$-Cells after EP $(\mathrm{EP}=1000 \mathrm{~V} / \mathrm{cm}$, $100 \mu \mathrm{s}, 8$ pulses, $1 \mathrm{~Hz}$; (d) - Cells after ECT with doxorubicin. Abbreviations: CSK-cytoskeleton; GA—Golgi apparatus; Ly-lysosomes; $\mathrm{M}$-mitochondria; $\mathrm{N}$-nucleus; Nc—nucleolus; RER—rough endoplasmic reticulum; V-vacuole; (original magnification 7A $\times 4400 ; 7 \mathrm{~B} \times 12600 ; 7 \mathrm{C}, 7 \mathrm{D} \times 7000$ ).

Control cells MCF-7/DOX (Figure 11a) are characterized by the nucleus of irregular shape with nuclear envelope invaginations and prominent nucleoli with well-developed fibrillar centers, located at the center of the nucleus. Electron-dense chromatin is situated under the nuclear envelope. In the cytoplasm condensed mitochondria, RER, elements of cytoskeleton and Golgi apparatus were visible. After exposure to DOX (Figure 11b) smaller rounded mitochondria were densely packed with cristae and bigger extended mitochondria with marginal cristae with a granular and homogenous inner compartment. After electropermeabilization alone (Figure 11c) a lot of abnormal vacuoles with fibrous, heterogeneous and flocculent material were detected. Resistant cells have a nucleus of irregular shape with invaginations and active nucleoli located near the nuclear membrane that could be considered as a pattern of activated metabolism in the cell that acquired drug resistance. In the case of electric pulses together with DOX (Figure 11d), spherical lysosomes with heterogeneous dark content, heterogeneous material characteristic to secondary lysosomes and vacuoles with more irregular shaped were observed.

Analysis of the cellular ultrastructure revealed that MCF-7/WT cells are more sensitive to applied both electric field and DOX that causes more expressed cytotoxic alterations than MCF-7/DOX cell lines. 
In the majority of cells dystrophic changes were detected that were manifested with the significant vacuolization of cell cytoplasm, decrease of the number of cytoplasmic organelles and the diversification in shape and inner structure of mitochondria. The number of cells with significant alterations evoked by the toxicity was higher in cells treated with the combination of EP and DOX, compared to cells treated with drug or electric pulses alone. After electroporation, in the majority of studied cells, nuclei with low electronic density and cytoplasm with a large number of vacuoles and dense single mitochondria were observed.

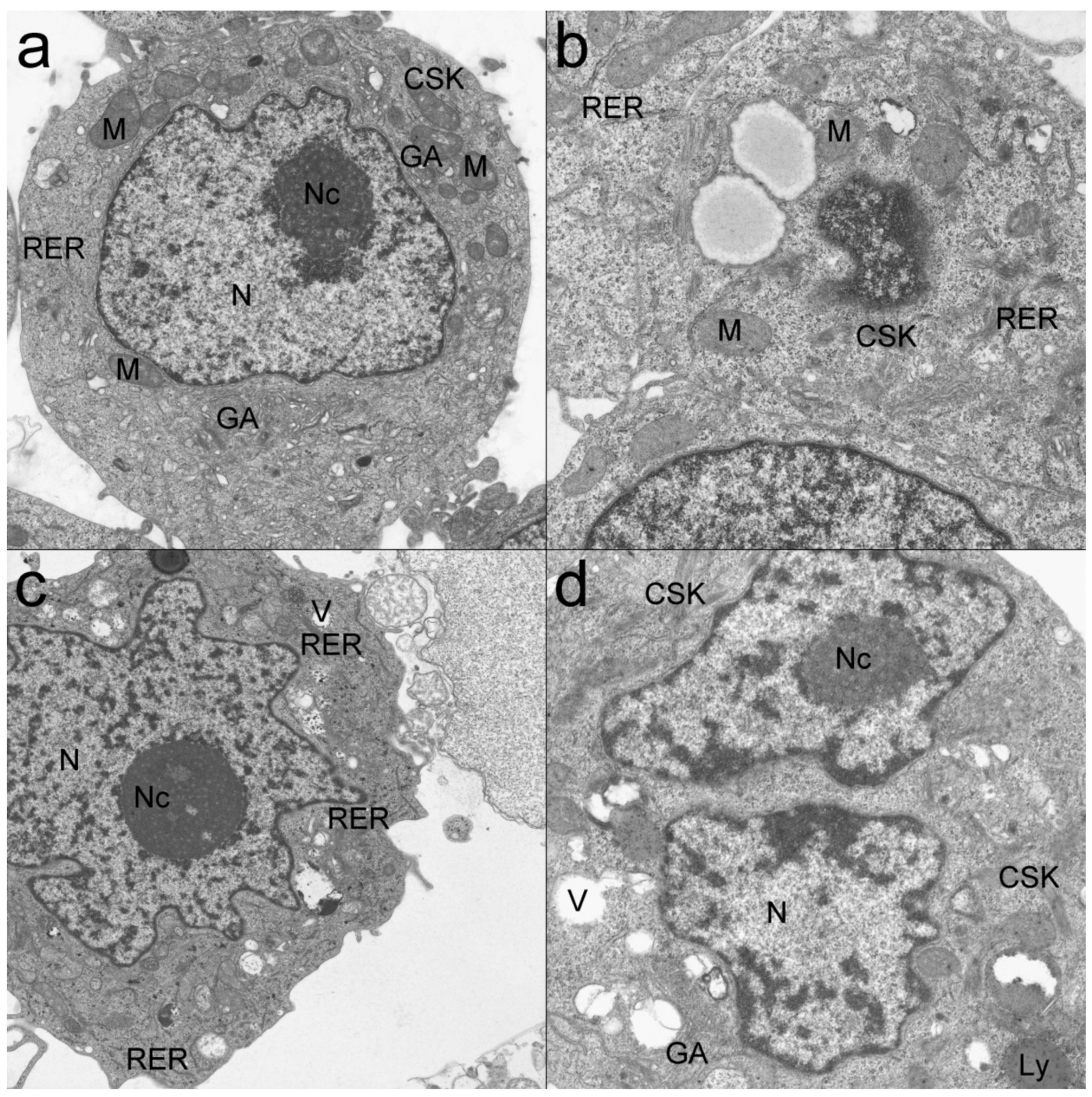

Figure 11. Ultrastructure of breast adenocarcinoma doxorubicin-resistant cells (MCF-7/DOX). (A) —Control, nontreated cells; $(\mathbf{B})$ —Cells after exposure to doxorubicin (DOX = 1.7 $\mu \mathrm{M})$; $(\mathbf{C})$-Cells after EP $(\mathrm{EP}=$ $1000 \mathrm{~V} / \mathrm{cm}, 100 \mu \mathrm{s}, 8$ pulses, $1 \mathrm{~Hz}$ ); (D)—Cells after ECT with doxorubicin. Abbreviations: CSK—cytoskeleton; GA-Golgi apparatus; Ly-Lysosome; $\mathrm{M}$-mitochondria; $\mathrm{N}$-nucleus; Nc-nucleolus; RER—rough endoplasmic reticulum; V-vacuole; (original magnification 8A, 8B, 8C $\times 7000$; $8 \mathrm{D} \times 2600$ ).

Electron microscopy evaluation has demonstrated that nuclei drug-resistance cells are characterized by the appearance of notable regions of heterochromatin located close to the inner side of the nuclear membrane, and possess a rugged shape of the nucleus due to the appearance of nuclear membrane invagination that respectively increases its area (MCF-7/DOX, EP and EP + DOX). Such patterns were not observed in drug-sensitive cells. In the nucleus one or sometimes three nucleoli are detected. Cells MCF-7/DOX are characterized by a higher density that is related to a large number of free ribosomes that tend to aggregate. 


\section{Discussion}

The application of electric field pulses to cancer cells results in the permeabilization of their plasma membrane. This technique specifies the application of short high-voltage pulses to penetrate the barrier of the cell membrane. Electroporation can be a very efficient method for introducing molecules into cells, including various non-permeant molecules, which could significantly enhance the cytotoxicity [37].

Optimizing electroporation parameters is crucial for the future application and can be easily performed in cell suspension using, e.g., propidium iodide [38,39] or lucifer yellow [40]. The electric field intensity is the key parameter in electrochemotherapeutic protocols as it should lead to the pore formation without simultaneous cell destruction. In our study the following electroporation parameters were applied: 8 square pulses, $100 \mu \mathrm{s}$ width, delivered at $1 \mathrm{~Hz}$ frequency, which corresponded to ESOPE protocol [34]. Our previous study demonstrated that the application of electric pulses increases cell membrane permeability to propidium iodide in human breast adenocarcinoma cells [14,32,41,42]. The dose of DOX with no cytotoxic effect was determined using a metabolic activity assay. There are few papers discussing electroporation in combination with DOX. However, these reports indicate that DOX causes a dose-dependent decrease in cell viability. The available studies of other research teams have shown that the use of electroporation using DOX in vitro in MCF-7 cells increases the absorption of the drug and causes an increased cytotoxicity [24]. Satisfactory results were obtained by DOX loading in biodegradable micelles in a mouse hepatocellular carcinoma xenograft model, using two electroporation variants: reversible for parameter $500 \mathrm{~V} / \mathrm{cm}$ and irreversible for parameter 2500 $\mathrm{V} / \mathrm{cm}$. A three-fold increase in DOX uptake in the cell nucleus was observed when using micelles and irreversible electroporation compared to the micelles alone. Authors observed in these cells an increase in reactive oxygen species, abnormalities in mitochondria, and an increase in intracellular calcium [43]. In the case of clinical research it was revealed that $5 \mu \mathrm{M}$ was the maximum drug concentration observed in the plasma of patients after intravenous administration [43].

The energy levels necessary for the electroporation-supported therapy are similar to the intensities used for ECT in vivo [44]. For the successive clinical electrochemotherapy of human breast cancer with bleomycin, Whelan et al. applied pulses of intensity $1400 \mathrm{~V} / \mathrm{cm}, 100 \mu$ s duration [45]. Xiao et al., showed that low voltage pulses $200 \mathrm{~V} / \mathrm{cm}$ with longer duration ( 20 and $40 \mathrm{~ms}, 8$ pulses, $1 \mathrm{~Hz}$ ) are also effective towards permeabilization in MCF-7 breast cancer cell in vitro [46]. Cemazar et al. proved that the intensity of $800-1000 \mathrm{~V} / \mathrm{cm}$ (pulse duration $100 \mu \mathrm{s}, 8$ pulses, $1 \mathrm{~Hz}$ ) was the most appropriate for electroporation of MCF-7/WT cancer cells in vitro [47]. Shil et al. reported on the effects of a combination of local electroporation with ionizing radiation and DOX on subcutaneous solid tumor murine fibrosarcoma. These results suggest that the antitumor effects of gamma radiation and a low concentration of DOX can be enhanced by combination with electroporation [48].

Several studies have shown that intracellular accumulation and location of cytostatics have a significant impact on their cytotoxic properties and pharmacological characteristics [49-51]. Here, we have also demonstrated DOX location inside cells by LSCM studies. Cells incubated with DOX showed high drug accumulation in cell nuclei in both tested cell lines. DOX fluorescence intensity in sensitive cells increased proportionally to the increase in incubation time, whereas in resistant cells the fluorescence intensity was at a similar, constant level. Similar research results were obtained by other research groups [52,53]. The analysis of the distribution and elimination of DOX from the cells was performed in tests with and without the application of electrical impulses. It was indicated that DOX exposed to the electric field was not localized in the cell nucleus but was scattered throughout the entire cytoplasm. Presumably DOX shows a change in compound properties and an attenuation of fluorescent signal under EP influence. The fluorescence studies indicate that both cell lines differ in doxorubicin efflux after the application of a pulsed electric field. According to the mass spectrometry studies it could be stated that the electric field does not affect doxorubicin's structure, but rather affects the biological properties of the cells. We presume that EP affects the doxorubicin's membrane transporters in such a way that they cannot effectively release the cytostatic from the cell. Studies conducted by 
Lou et al. on MCF-7 and MCF-7/ADR cells have shown intensive nuclear localization of DOX [54]. Meschini et al. have not observed at all or observed a weak fluorescent signal mainly in the cytoplasm of LOVO/DX cells incubated for 1 to $3 \mathrm{~h}$ with DOX [55]. After electroporation, a more favorable intranuclear localization was observed. The evaluation of the morphology of electroporated cells at the ultrastructure level showed a large number of vacuoles with fibrous flocculent material. Meschini et al. obtained similar results after electroporation with DOX [55] and electroporation alone [56].

\section{Conclusions}

Electroporation-based methods are efficiently applied for drug delivery as a supportive technique for electrochemotherapy. Numerous studies demonstrate cellular effects provoked by electroporation. In our work we presented a comprehensive evaluation of the effect of a pulsed electric field with doxorubicin on morphology and cellular compartments in breast adenocarcinoma cells. Our research proved that manipulation with electroporation using DOX is an effective method against human breast cancer cells including resistant counterparts. Taking into consideration the quantity of available data and evidences, we suppose that "red chemotherapy" will be accompanied by permeabilization methods in the near future.

Author Contributions: Conceptualization, N.R. and J.K.; methodology, N.R.; validation, A.S.( Anna Szewczyk), J.S. and M.D.; formal analysis, W.S. and H.C.-I.; investigation, N.R.; resources, J.K.; data curation, N.R.; writing —original draft preparation, N.R.; writing—review and editing, J.K., M.D.-M. and J.S; visualization, N.R.; supervision, J.K. and A.S.( Andrzej Sikora); project administration, N.R.; funding acquisition, N.R. All authors have read and agreed to the published version of the manuscript.

Funding: This research was supported by National Science Centre (Poland) within a framework of PRELUDIUM, grant No. 2015/19/N/NZ7/01105, PI: N.Rembiałkowska.

Acknowledgments: We would like to thank M. Kotulska (Department of Biomedical Engineering, Wroctaw University of Science and Technology, Wrocław, Poland) for the possibility to perform electroporation tests on ECM 830 Square Wave Electroporation System (BTX Harvard Apparatus, Syngen Biotech, Poland), Sylwester Ślusarczyk (Department of Pharmaceutical Biology and Botany, Faculty of Pharmacy, Wroclaw Medical University, Poland) for the assistance in mass spectrometry analyses and expert support. We thank $\mathrm{O}$. Michel for the help in improve the English writing of the manuscript.

Conflicts of Interest: The authors declare no conflict of interest.

\section{References}

1. Gothelf, A.; Mir, L.M.; Gehl, J. Electrochemotherapy: Results of cancer treatment using enhanced delivery of bleomycin by electroporation. Cancer Treat. Rev. 2003, 5, 371-387. [CrossRef]

2. Loi, S.; Sirtaine, N.; Piette, F.; Salgado, R.; Viale, G.; Van Eenoo, F.; Rouas, G.; Francis, P.; Crown, J.P.A.; Hitre, E.; et al. Prognostic and predictive value of tumor-infiltrating lymphocytes in a phase III randomized adjuvant breast cancer trial in node-positive breast cancer comparing the addition of docetaxel to doxorubicin with doxorubicin-based chemotherapy: BIG 02-98. J. Clin. Oncol. 2013. [CrossRef] [PubMed]

3. Adams, S.; Gray, R.J; Demaria, S.; Goldstein, L.; Perez, E.A.; Shulman, L.N.; Martino, S.; Wang, M.; Jones, V.E.; Saphner, T.J.; et al. Prognostic value of tumor-infiltrating lymphocytes in triple-negative breast cancers from two phase III randomized adjuvant breast cancer trials: ECOG 2197 and ECOG 1199. J. Clin. Oncol. 2014, 32, 2959-2966. [CrossRef]

4. Mir, L.M.; Orlowski, S. Mechanisms of electrochemotherapy. Adv. Drug Deliv. Rev. 1999, 35, 107-118. [CrossRef]

5. Rols, M.P. Electropermeabilization, a physical method for the delivery of therapeutic molecules into cells. Biochim. Biophys. Acta Biomembr. 2006, 1758, 423-428. [CrossRef] [PubMed]

6. Yarmush, M.L.; Golberg, A.; Serša, G.; Kotnik, T.; Miklavčič, D. Electroporation-based technologies for medicine: Principles, Applications, and challenges. Annu. Rev. Biomed. Eng. 2014, 16, 295-320. [CrossRef]

7. Jaroszeski, M.J.; Heller, R.; Gilbert, R. Electrochemotherapy, Electrogenetherapy, and Transdermal Drug Delivery: Electrically Mediated Delivery of Molecules to Cells; University of South Florida Press: Tampa, FL, USA, 2000; ISBN 0896036065.

8. Gehl, J. Electroporation for drug and gene delivery in the clinic: Doctors go electric. In Electroporation Protocols; Humana Press: Totowa, NJ, USA, 2008; Volume 423, pp. 351-359. 
9. Campana, L.G.; Valpione, S.; Falci, C.; Mocellin, S.; Basso, M.; Corti, L.; Balestrieri, N.; Marchet, A.; Rossi, C.R. The activity and safety of electrochemotherapy in persistent chest wall recurrence from breast cancer after mastectomy: A phase-II study. Breast Cancer Res. Treat. 2012, 134, 1169-1178. [CrossRef]

10. Benevento, R.; Santoriello, A.; Perna, G.; Canonico, S. Electrochemotherapy of cutaneous metastastes from breast cancer in elderly patients: A preliminary report. BMC Surg. 2012. [CrossRef]

11. Davalos, R.V.; Mir, L.M.; Rubinsky, B. Tissue ablation with irreversible electroporation. Ann. Biomed. Eng. 2005. [CrossRef]

12. Rubinsky, B. Irreversible electroporation in medicine. Technol. Cancer Res. Treat. 2007. [CrossRef]

13. Dev, S.B.; Rabussay, D.P.; Widera, G.; Hofmann, G.A. Medical applications of electroporation. IEEE Trans. Plasma Sci. 2000, 28, 206-223. [CrossRef]

14. Weżgowiec, J.; Kulbacka, J.; Saczko, J.; Rossowska, J.; Chodaczek, G.; Kotulska, M. Biological effects in photodynamic treatment combined with electropermeabilization in wild and drug resistant breast cancer cells. Bioelectrochemistry 2018, 123, 9-18. [CrossRef] [PubMed]

15. Batista Napotnik, T.; Miklavčič, D. In vitro electroporation detection methods-An overview. Bioelectrochemistry 2018, 120, 166-182. [CrossRef] [PubMed]

16. Waks, A.G.; Winer, E.P. Breast Cancer Treatment: A Review. JAMA J. Am. Med. Assoc. 2019, 321, $288-300$. [CrossRef]

17. Sun, Y.S.; Zhao, Z.; Yang, Z.N.; Xu, F.; Lu, H.J.; Zhu, Z.Y.; Shi, W.; Jiang, J.; Yao, P.P.; Zhu, H.P. Risk factors and preventions of breast cancer. Int. J. Biol. Sci. 2017, 13, 1387-1397. [CrossRef]

18. Cai, F.; Luis, M.; Lin, X.; Wang, M.; Cai, L.; Cen, C.; Biskup, E. Anthracycline-induced cardiotoxicity in the chemotherapy treatment of breast cancer: Preventive strategies and treatment (Review). Mol. Clin. Oncol. 2019, 11, 15-23. [CrossRef]

19. Barretf-Lee, P.J. Growth factor signalling in clinical breast cancer and its impact on response to conventional therapies: A review of chemotherapy. Endocr-Relat. Cancer 2005, 12, 125-133. [CrossRef]

20. Canela, A.; Maman, Y.; Jung, S.; Wong, N.; Callen, E.; Day, A.; Kieffer-Kwon, K.R.; Pekowska, A.; Zhang, H.; Rao, S.S.P.; et al. Genome organization drives chromosome fragility. Cell 2017, 170, 507-521. [CrossRef]

21. Henriksen, P.A. Anthracycline cardiotoxicity: An update on mechanisms, monitoring and prevention. Heart 2018, 104, 971-977. [CrossRef]

22. Avril, T.; Vauléon, E.; Chevet, E. Endoplasmic reticulum stress signaling and chemotherapy resistance in solid cancers. Oncogenesis 2017, 6, 373. [CrossRef]

23. Zhao, N.; Martin, C.; Woodle, M.; Mixson, A.J. Advances in delivery systems for doxorubicin. J. Nanomed. Nanotechnol. 2018, 9, 519. [CrossRef] [PubMed]

24. Rodrigues, P.G.; Miranda-Silva, D.; Costa, S.M.; Barros, C.; Hamdani, N.; Moura, C.; Mendes, M.J.; Sousa-Mendes, C.; Trindade, F.; Fontoura, D.; et al. Early myocardial changes induced by doxorubicin in the nonfailing dilated ventricle. Am. J. Physiol.-Heart Circ. Physiol. 2019, 316. [CrossRef] [PubMed]

25. Teissié, J.; Escoffre, J.M.; Paganin, A.; Chabot, S.; Bellard, E.; Wasungu, L.; Rols, M.P.; Golzio, M. Drug delivery by electropulsation: Recent developments in oncology. Int. J. Pharm. 2012, 423, 3-6. [CrossRef] [PubMed]

26. Pehlivanova, V.N.; Tsoneva, I.H.; Tzoneva, R.D. Multiple effects of electroporation on the adhesive behaviour of breast cancer cells and fibroblasts. Cancer Cell Int. 2012, 12, 9. [CrossRef] [PubMed]

27. Gibot, L.; Wasungu, L.; Teissié, J.; Rols, M.P. Antitumor drug delivery in multicellular spheroids by electropermeabilization. J. Control. Release 2013, 167, 138-147. [CrossRef]

28. Elmore, S. Apoptosis: A review of programmed cell death. Toxicol. Pathol. 2007, 35, 495-516. [CrossRef]

29. Choromanska, A.; Lubinska, S.; Szewczyk, A.; Saczko, J.; Kulbacka, J. Mechanisms of antimelanoma effect of oat $\beta$-glucan supported by electroporation. Bioelectrochemistry 2018, 123, 255-259. [CrossRef]

30. Kulbacka, J.; Pucek, A.; Wilk, K.A.; Dubińska-Magiera, M.; Rossowska, J.; Kulbacki, M.; Kotulska, M. The effect of millisecond pulsed electric fields (msPEF) on intracellular drug transport with negatively charged large nanocarriers made of solid lipid nanoparticles (SLN): In vitro study. J. Membr. Biol. 2016, 249, 645-661. [CrossRef]

31. Kulbacka, J.; Kotulska, M.; Rembiałkowska, N.; Choromańska, A.; Kamińska, I.; Garbiec, A.; Rossowska, J.; Daczewska, M.; Jachimska, B.; Saczko, J. Cellular stress induced by photodynamic reaction with CoTPPS and MnTMPyPCl5 in combination with electroporation in human colon adenocarcinoma cell lines (LoVo and LoVoDX). Cell Stress Chaperones 2013, 18, 719-731. [CrossRef] 
32. Wezgowiec, J.; Derylo, M.B.; Teissie, J.; Orio, J.; Rols, M.P.; Kulbacka, J.; Saczko, J.; Kotulska, M. Electric field-assisted delivery of photofrin to human breast carcinoma cells. J. Membr. Biol. 2013, 246, 725-735. [CrossRef]

33. Marty, M.; Sersa, G.; Garbay, J.R.; Gehl, J.; Collins, C.G.; Snoj, M.; Billard, V.; Geertsen, P.F.; Larkin, J.O.; Miklavcic, D.; et al. Electrochemotherapy-An easy, highly effective and safe treatment of cutaneous and subcutaneous metastases: Results of ESOPE (European Standard Operating Procedures of Electrochemotherapy) study. Eur. J. Cancer Suppl. 2006, 4. [CrossRef]

34. Romeo, S.; Sannino, A.; Scarfi, M.R.; Vernier, P.T.; Cadossi, R.; Gehl, J.; Zeni, O. ESOPE-Equivalent pulsing protocols for calcium electroporation: An in vitro optimization study on 2 cancer cell models. Technol. Cancer Res. Treat. 2018, 17, 1533033818788072. [CrossRef]

35. Ma, W.; Wang, J.; Guo, Q.; Tu, P. Simultaneous determination of doxorubicin and curcumin in rat plasma by LC-MS/MS and its application to pharmacokinetic study. J. Pharm. Biomed. Anal. 2015, 111, $215-221$. [CrossRef] [PubMed]

36. Reynolds, E.S. The use of lead citrate at high $\mathrm{pH}$ as an electron-opaque stain in electron microscopy. J. Cell Biol. 1963, 17, 208-212. [CrossRef] [PubMed]

37. Cemazar, M.; Parkins, C.S.; Holder, A.L.; Chaplin, D.J.; Tozer, G.M.; Sersa, G. Electroporation of human microvascular endothelial cells: Evidence for an anti-vascular mechanism of electrochemotherapy. Br. J. Cancer 2001, 84, 565-570. [CrossRef] [PubMed]

38. Gabriel, B.; Teissié, J. Direct observation in the millisecond time range of fluorescent molecule asymmetrical interaction with the electropermeabilized cell membrane. Biophys. J. 1997, 75, 2630-2637. [CrossRef]

39. Serša, G.; čemažar, M.; Miklavčič, D. Antitumor effectiveness of electrochemotherapy with cis-Diamminedichloroplatinum(II) in mice. Cancer Res. 1995, 55, 3450-3455.

40. Dinchuk, J.E.; Kelley, K.A.; Callahan, G.N. Flow cytometric analysis of transport activity in lymphocytes electroporated with a fluorescent organic anion dye. J. Immunol. Methods 1992, 155, 257-265. [CrossRef]

41. Saczko, J.; Nowak, M.; Skolucka, N.; Kulbacka, J.; Kotulska, M. The effects of the electro-photodynamic in vitro treatment on human lung adenocarcinoma cells. Bioelectrochemistry 2010, 79, 90-94. [CrossRef]

42. Skolucka, N.; Daczewska, M.; Saczko, J.; Chwilkowska, A.; Choromanska, A.; Kotulska, M.; Kaminska, I.; Kulbacka, J. ETM study of electroporation influence on cell morphology in human malignant melanoma and human primary gingival fibroblast cells. Asian Pac. J. Trop. Biomed. 2011, 1, 94-98. [CrossRef]

43. Maillet, A.; Tan, K.; Chai, X.; Sadananda, S.N.; Mehta, A.; Ooi, J.; Hayden, M.R.; Pouladi, M.A.; Ghosh, S.; Shim, W.; et al. Modeling doxorubicin-induced cardiotoxicity in human pluripotent stem cell derived-cardiomyocytes. Sci. Rep. 2016. [CrossRef] [PubMed]

44. Novickij, V.; Zinkevičienè, A.; Perminaitè, E.; Čèsna, R.; Lastauskienè, E.; Paškevičius, A.; Švedienè, J.; Markovskaja, S.; Novickij, J.; Girkontaite, I. Non-invasive nanosecond electroporation for biocontrol of surface infections: An in vivo study. Sci. Rep. 2018. [CrossRef] [PubMed]

45. Whelan, M.C.; Larkin, J.O.; Collins, C.G.; Cashman, J.; Breathnach, O.; Soden, D.M.; O'Sullivan, G.C. Effective treatment of an extensive recurrent breast cancer which was refractory to multimodal therapy by multiple applications of electrochemotherapy. Eur. J. Cancer Suppl. 2006, 4, 32-34. [CrossRef]

46. Xiao, F.; Salameh, T.; Camarillo, I.; Dykstra, C.; Lenarduzzi, N.; Reece, L.; Leary, J.F.; Natarajan, A.; Sundararajan, R. Electrically-enhanced chemodrug delivery to human breast cancer cells. In Proceedings of the Electrostatic Society of America Annual Meeting, Boston, MA, USA, 16-18 June 2009.

47. Čemažar, M.; Jarm, T.; Miklavčič, D.; Lebar, A.M.; Ihan, A.; Kopitar, N.A.; Serša, G. Effect of electric-field intensity on electropermeabilization and electrosensitivity of various tumor-cell lines in vitro. Electromagn. Biol. Med. 1998, 263-272. [CrossRef]

48. Shil, P.; Kumar, A.; Vidyasagar, P.B.; Mishra, K.P. Electroporation enhances radiation and doxorubicin-induced toxicity in solid tumor in vivo. J. Environ. Pathol. Toxicol. Oncol. 2006, 25, 625-632. [CrossRef]

49. Beyer, U.; Rothen-Rutishauser, B.; Unger, C.; Wunderli-Allenspach, H.; Kratz, F. Differences in the intracellular distribution of acid-sensitive doxorubicin-protein conjugates in comparison to free and liposomal formulated doxorubicin as shown by confocal microscopy. Pharm. Res. 2001, 18, 29-38. [CrossRef]

50. Wu, J.; Lu, Y.; Lee, A.; Pan, X.; Yang, X.; Zhao, X.; Lee, R.J. Reversal of multidrug resistance by transferrinconjugated liposomes co-encapsulating doxorubicin and verapamil. J. Pharm. Pharm. Sci. 2007, 10, 350-357.

51. Xu, D.H.; Gao, J.Q.; Liang, W.Q. Liposome-based intracellular kinetics of doxorubicin in K562/DOX cells. Pharmazie 2008, 63, 646-649. 
52. Ho, J.A.A.; Fan, N.C.; Fang-Ju Jou, A.; Wu, L.C.; Sun, T.P. Monitoring the subcellular localization of doxorubicin in CHO-K1 using MEKC-LIF: Liposomal carrier for enhanced drug delivery. Talanta 2012, 99, 683-688. [CrossRef]

53. Zeng, X.; Morgenstern, R.; Nyström, A.M. Nanoparticle-directed sub-cellular localization of doxorubicin and the sensitization breast cancer cells by circumventing GST-mediated drug resistance. Biomaterials 2014, 35, 1227-1239. [CrossRef]

54. Lou, P.J.; Lai, P.S.; Shieh, M.J.; MacRobert, A.J.; Berg, K.; Bown, S.G. Reversal of doxorubicin resistance in breast cancer cells by photochemical internalization. Int. J. Cancer 2006, 119, 2692-2698. [CrossRef] [PubMed]

55. Meschini, S.; Condello, M.; Lista, P.; Vincenzi, B.; Baldi, A.; Citro, G.; Arancia, G.; Spugnini, E.P. Electroporation adopting trains of biphasic pulses enhances in vitro and in vivo the cytotoxic effect of doxorubicin on multidrug resistant colon adenocarcinoma cells (LoVo). Eur. J. Cancer 2012, 48, 2236-2243. [CrossRef] [PubMed]

56. Zhou, W.; Xiong, Z.; Liu, Y.; Yao, C.; Li, C. Low voltage irreversible electroporation induced apoptosis in HeLa cells. J. Cancer Res. Ther. 2012, 8, 80-85. [CrossRef] [PubMed]

(C) 2020 by the authors. Licensee MDPI, Basel, Switzerland. This article is an open access article distributed under the terms and conditions of the Creative Commons Attribution (CC BY) license (http://creativecommons.org/licenses/by/4.0/). 